\title{
A medicoeconomic review of early intervention with biologic agents in the treatment of inflammatory bowel diseases
}

This article was published in the following Dove Press journal:

ClinicoEconomics and Outcomes Research

8 October 2014

Number of times this article has been viewed

\author{
Shmuel Odes' \\ Dan Greenberg ${ }^{2}$ \\ 'Department of Gastroenterology \\ and Hepatology, Faculty of Health \\ Sciences, Ben-Gurion University \\ of the Negev, Beer Sheva, Israel; \\ ${ }^{2}$ Department of Health Systems \\ Management, Faculty of Health \\ Sciences and Guilford Glazer Faculty \\ of Business and Management, Ben- \\ Gurion University of the Negev, Beer \\ Sheva, Israel
}

\begin{abstract}
The treatment of inflammatory bowel disease with standard therapy fails to control the disease in many patients. Biologic therapy has an increasing role in altering the natural history of Crohn's disease and ulcerative colitis, and is improving patient prognosis. However, indications for treatment and issues with drug costs and value for money remain unclear. Also, when to perform early intervention with biologic agents is at present unclear. We performed an extensive literature search and review to address these issues. The biologics provide better care for many patients. The choice of biologic agent, the indications for its use, the switch between agents, and the considerations of cost are outlined, with a view to guiding the treating physician in managing these cases. Outstanding issues and anticipated future developments are defined. Keywords: biologic therapy, ulcerative colitis, Crohn's disease, cost-effectiveness
\end{abstract}

\section{Introduction}

Inflammatory bowel disease (IBD) comprises three entities: ulcerative colitis (UC), Crohn's disease (CD), and "inflammatory bowel disease - unclassified" (IBD-U). ${ }^{1}$ In a recent large European incidence study, IBD-U accounted for $11 \%$ of all IBD cases. ${ }^{2}$ The etiology of IBD is unknown, but the incidence is generally increasing, particularly in Asia, where IBD was rare in the past. UC is a disease of the colon and rectum; ileal involvement is rare. The inflammation involves the mucosa; deeper penetration is uncommon. $\mathrm{CD}$ is a transmural disease of the small or large bowel or of both in various combinations; occasionally, more proximal involvement is seen. CD can occur as inflammatory, stricturing, and penetrating (fistulous) disease, and the pattern can change with time from purely inflammation to the more complicated phenotypes. The course of UC and CD is variable among patients, but an overall pattern has been modeled mathematically for $\mathrm{CD} .{ }^{3}$ It is estimated that some $50 \%$ of patients will have active disease at any point in time. ${ }^{4}$ All these diseases are incurable; they last a lifetime, can have considerable morbidity, and often require "heavy" medication and surgery. There are considerable impairments of social functioning and the ability to learn and work. Procreativity is affected. The health care burden of these diseases is immense and is increasing.

The current treatment of IBD is complex and consists of nutritional and psychosociological support, pharmacotherapy, and surgery where specifically indicated. Standard or conventional therapy includes 5-aminosalicylic acid, corticosteroids, and immunomodulators. ${ }^{5}$ In recent years, biologic agents have been introduced for use in CD and UC patients who failed conventional therapy in the "step-up" approach (standard therapy given first, and biologics for the failures of standard therapy) and
Department of Gastroenterology and Hepatology, Faculty of Health Sciences, Ben-Gurion University of the Negev, PO Box 15I, Beer Sheva 84I0I, Israel Tel +972522700752

Fax +97286233083

Email odes@bgu.ac.il 
as a first-line agent for CD patients with fistulae. ${ }^{6}$ In selected CD patients without a fistula, the use of biologics de novo has been tested in what has been dubbed the "step-down" or "top-down" approach. ${ }^{7}$ Biologic treatments have changed the entire concept of the management of IBD since they yield a high rate of induction and maintenance of deep mucosal (or histological) healing, which has become the major end point of therapy in the modern approach. The attainment of mucosal healing with the biologic agents may, for the first time, lead to a change in the natural course of disease by decreasing irreversible bowel damage and avoiding surgery. ${ }^{8}$ Introduction of biologic therapy within 30 days of diagnosis (with or without prior standard therapy) has been defined as "early biologic intervention".

This review will examine the present role of biologics in the acute treatment of IBD and their cost-effectiveness; drug trials and economic models of the biologics will be examined in detail. Although consideration of side effects (some are quite serious) remains very important, the major factor limiting the use of biologics is their exorbitant acquisition price. ${ }^{9}$ Therefore, the place of expensive biologic therapy in the developing world will be considered as well.

\section{Materials and methods}

English language peer-reviewed articles published through March 31, 2014 were obtained by an extensive search in PubMed, EMBASE, the Cochrane Library, and others, and from references contained in the solicited articles, beginning in the year 1990, using search terms such as: "ulcerative colitis", "Crohn's disease", "indeterminate colitis", "IBDunclassified", "economics", "cost", “cost-effectiveness", "cost savings", "incremental cost-effectiveness ratio (ICER)", "quality-adjusted life-years (QALYs)", and the names of the various biologic agents with proven or apparent clinical use. We also used the Tufts Medical Center Cost-Effectiveness Analysis Registry to search for relevant economic evaluations. Drugs in development and biosimilars were not considered, since their cost and clinical benefit, and therefore their economic benefit, are yet unknown. For clinical evaluations we reviewed original research articles, reviews, and technical reports pertaining to adult patients. Economic studies of interest included cost-effectiveness analyses (CEAs) of biologic agents presenting a cost per QALY ICER and were either CEAs using patient-level data (ie, conducted alongside a clinical study or clinical trial) or decision analytic models. We excluded review, editorial, and methodological articles, and CEAs that measured health outcomes in units other than QALYs, as well as analyses published prior to 2007. We excluded CEAs not examining biologic drugs or comparing biologics with immunosuppressants in the absence of a placebo arm. We also searched ClinicalTrials.gov using the terms "ulcerative colitis", "Crohn's disease", and "cost" to identify ongoing economic studies conducted alongside a clinical trial.

For each relevant CEA we present a description of the intervention, its comparator, the target population, the study perspective, the time horizon used for the analysis, and the ICERs as presented in the Tufts Medical Center Cost-Effectiveness Analysis Registry. CEAs may present more than one ICER, eg, when more than two interventions (eg, drugs) are compared, when various doses or treatment duration of the same drug are examined, and for different target populations in which the intervention is used. As studies were performed in various countries, using different currencies and reference years for costs, we converted all ICERs to US dollars using the relevant exchange factor and inflated to 2013 values using the US Consumer Price Index. Based on commonly accepted practice, an intervention with an ICER $<\$ 50,000 /$ QALY (approximately the US gross domestic product [GDP] per capita) was deemed to be highly cost-effective, a ratio of $\$ 50,000-\$ 100,000 /$ QALY was considered cost-effective, and an ICER $>\$ 100,000$ suggested that the intervention was not cost-effective.

\section{Results}

\section{Mode of action of anti-tumor necrosis- $\alpha$ agents}

The biologic agents can be classified by their primary mode of action (Table 1). Tumor necrosis factor- $\alpha$ (TNF- $\alpha$ ) is a proinflammatory cytokine thought to contribute to mucosal inflammation in the intestines in CD and UC through a variety of mechanisms, including disruption of the mucosal barrier,

Table I Common biologic treatments for inflammatory bowel diseases

\begin{tabular}{lll}
\hline Class & Drugs & Current indications \\
\hline Anti-TNF- $\alpha$ monoclonal & Infliximab & $\mathrm{CD}, \mathrm{UC}$ \\
antibodies & Adalimumab & $\mathrm{CD}, \mathrm{UC}$ \\
& Golimumab & $\mathrm{UC}, \mathrm{CD}$ \\
& Certolizumab & $\mathrm{CD}$ \\
Inhibition of leukocyte & Natalizumab & $\mathrm{CD}$ \\
trafficking & Vedolizumab & $\mathrm{UC}, \mathrm{CD}$ \\
& Etrolizumab* & $\mathrm{UC}$ \\
T-cell depletion & Ustekinumab* & $\mathrm{CD}$ \\
\hline
\end{tabular}

Notes: *In trials, not yet approved for general use. Biosimilars of infliximab are not considered in this review.

Abbreviations: TNF, tumor necrosis factor; CD, Crohn's disease; UC, ulcerative colitis. 
promotion of apoptosis of intestinal epithelial cells, and induction of intestinal chemokine secretion. ${ }^{10}$ Monoclonal antibodies (mAbs) (immunoglobulins [Ig]) have been developed to specifically target transmembrane and soluble TNF- $\alpha$ molecules.

Three anti-TNF- $\alpha$ mAbs are US Food and Drug Administration (FDA)-approved for use in CD: infliximab (IFX), adalimumab (ADA), and certolizumab pegol (CZP). IFX and ADA are also approved in Europe. IFX and, more recently, ADA are approved for use in UC in the US and Europe; golimumab is now licensed in the US for use in UC. IFX is a chimeric IgG (75\% human, $25 \%$ murine) $\mathrm{mAb}$ given intravenously. ADA is a fully humanized recombinant $\mathrm{mAb}$ injected subcutaneously. CZP is a pegylated, recombinant, fully humanized, antigen-binding fragment of a TNF mAb with less immunogenic potential. Like ADA, it is injected subcutaneously. Following a loading dose at onset of treatment, these agents have a linear relationship between the dose administered and the resulting plasma concentration achieved. The median half-life is shorter for IFX (7.7-9.5 days) than for ADA or CZP (2 weeks or more). These antibodies, being exogenous proteins introduced into the human host, are immunogenic, and their half-life is particularly affected by the presence of anti-TNF- $\alpha$ antibodies in the serum. Measurement of trough drug concentration and of antidrug antibody levels has become essential for monitoring patients on these therapies. There appears to be some correlation between IFX or ADA trough levels and the expected therapeutic response, but this has been difficult to demonstrate for CZP. With all agents, drug efficacy diminishes over time, the so-called secondary nonresponse. This failure rate may be lessened by adding azathioprine (AZA) to the therapeutic regime. An important consideration is that a certain percentage of naïve patients will be refractory to anti-TNF- $\alpha$ therapy from the outset, the so-called primary nonresponse. Since the armamentarium of approved biologic agents in most countries is limited to IFX and ADA, it is essential to optimize treatment with the first agent before making a change to the second drug.

\section{Efficacy of anti-TNF- $\alpha$ medication in CD}

This topic was the subject of two recent reviews. Ford et $\mathrm{al}^{11}$ performed a meta-analysis of the efficacy of biologic therapies in IBD. Induction of remission rates in CD (drop of Crohn's Disease Activity Index [CDAI] to 150 or lower) for IFX (at weeks 10-12), ADA (at week 4), and CZP (at weeks 6-12) in CD was $45.3 \%, 24.2 \%$, and $24.7 \%$, respectively. Kawalec et al ${ }^{12}$ carried out a meta-analysis of 18 randomized controlled trials and one clinical controlled trial, double-blinded and using a parallel group design, of induction (4 weeks of therapy) therapy with three anti-TNF- $\alpha$ agents in CD patients. ${ }^{13-26}$ Remission in moderate-to-severe nonfistulizing and fistulizing $\mathrm{CD}$ was based on a drop of the CDAI to 150 or less. IFX was tested in five trials, and ADA and CZP were each tested in six. There were two studies of IFX versus ADA. All three agents were statistically more effective than placebo for induction of remission at week 4 , with overall odds ratios (ORs) favoring the intervention as against placebo. Rates of fistula closure were also evaluated in two studies, showing $>50 \%$ reduction in the number of fistulas with IFX or ADA versus placebo.

In looking specifically at the effect of early intervention with biologic agents, it is important to examine remission rates achievable in the short term (Table 2). The 14 studies shown examined the effects of ADA, CZP, IFX, natalizumab, golimumab, and, in two cases, IFX combined with AZA in placebo-controlled trials in patients with CD and UC. The patients had all failed standard therapy prior to randomization to biologic therapy or placebo, and the CD patients included a wide spectrum of disease manifestations, some with fistulae. The timeframe was 4-8 weeks for most studies, and remission in $\mathrm{CD}$ was defined by standard drop of activity indices. IFX and ADA were significantly better than placebo in inducing remission in $\mathrm{CD}$ patients, but it was more difficult to show similar efficacy for CZP. In one study, natalizumab was effective only in $\mathrm{CD}$ patients with an elevated $\mathrm{C}$-reactive protein level. In the single top-down study of D'Haens et al, ${ }^{20}$ IFX was given with AZA at the onset of treatment and had a better steroid-sparing effect than a step-up regimen where IFX was added as a last resort. Taken together, these ten studies show that it is possible to achieve remission in $\mathrm{CD}$ patients within a short time span at rates of about $30 \%$ in CD treated with ADA, IFX, or natalizumab. Stidham et $\mathrm{al}^{27}$ performed a systematic review with network meta-analysis of trials of IFX, ADA, and CZP against placebo as comparator in CD patients. They found that there was no evidence of clinical superiority among these anti-TNF- $\alpha$ agents, although ADA was better than CZP for induction of remission. It is now evident that combination therapy using anti-TNF- $\alpha$ together with an immunomodulator gives higher remission rates than either agent alone in $\mathrm{CD}^{23}$ and $\mathrm{UC} .{ }^{18}$ To date, there is no trial of early intervention with biologic agents where, for example, IFX or ADA is given at diagnosis for CD patients deemed to be at risk for serious forms of disease, to determine whether the long-term outcome will be better than early introduction of biologics when standard therapy was to no avail. Scheduled 
Table 2 Remission rates for biologic therapy in CD and UC patients in a short timeframe

\begin{tabular}{|c|c|c|c|c|c|c|}
\hline Disease & Intervention & $\begin{array}{l}\text { Cohort } \\
\text { size }\end{array}$ & $\begin{array}{l}\text { Timeframe } \\
\text { (weeks) }\end{array}$ & $\begin{array}{l}\text { Remission } \\
\text { (\%) }\end{array}$ & $P$ & Reference \\
\hline \multirow[t]{2}{*}{$\overline{C D}$} & ADA & 76 & 4 & 36 & 0.001 & Hanauer et al $^{13}$ \\
\hline & Placebo & 74 & & 12 & & \\
\hline \multirow[t]{2}{*}{$C D$} & ADA & 159 & 4 & 21 & 0.001 & Sandborn et al ${ }^{14}$ \\
\hline & Placebo & 166 & & 7 & & \\
\hline \multirow[t]{2}{*}{$C D$} & CZP & 215 & 6 & 32 & 0.174 & Sandborn et al ${ }^{15}$ \\
\hline & Placebo & 223 & & 25 & & \\
\hline \multirow[t]{2}{*}{$C D$} & CZP various & 23 & 4 & 47.1 & 0.041 & Winter et $\mathrm{al}^{16}$ \\
\hline & Placebo & 24 & & 16 & & \\
\hline CD (with & CZP & 24 & 6 & 12 & NS & Schreiber et al ${ }^{17}$ \\
\hline fistula) & Placebo & 15 & & 10 & & \\
\hline \multirow[t]{3}{*}{$C D$} & IFX & 169 & 6 & 29.6 & $<0.001$ vs $A Z A$ & Colombel et al ${ }^{18}$ \\
\hline & $\mathrm{IFX}+\mathrm{AZA}$ & 169 & & 32.5 & $<0.001$ vs $A Z A$ & \\
\hline & AZA & 170 & & 14.1 & & \\
\hline \multirow[t]{2}{*}{$C D$} & IFX & 27 & 4 & 33 & 0.002 & Targan et al $^{19}$ \\
\hline & Placebo & 25 & & 4 & & \\
\hline \multirow[t]{2}{*}{$C D$} & $\mathrm{IFX}+\mathrm{AZA}$ & 67 & 14 & 64 & 0.001 & $\mathrm{D}^{\prime}$ Haens et $\mathrm{a}^{20}$ \\
\hline & Step-up to IFX & 66 & & 34 & & \\
\hline \multirow[t]{2}{*}{$C D$} & Natalizumab & 259 & 8 & 26 & 0.002 & Targan et $\mathrm{al}^{21}$ \\
\hline & Placebo & 280 & & 16 & & \\
\hline CD (with & Natalizumab & 526 & 10 & 40 & $<0.05$ & Sandborn et $\mathrm{al}^{22}$ \\
\hline raised CRP) & Placebo & 134 & & 28 & & \\
\hline \multirow[t]{2}{*}{ UC } & IFX & 121 & 8 & 33.9 & $<0.001$ & Rutgeerts et $\mathrm{al}^{23}$ \\
\hline & Placebo & 123 & & 5.7 & & \\
\hline \multirow[t]{2}{*}{ UC } & $\mathrm{ADA}$ & 130 & 8 & 18.5 & $<0.03$ & Reinisch et $\mathrm{a}^{24}$ \\
\hline & Placebo & 130 & & 9.2 & & \\
\hline \multirow[t]{2}{*}{ UC } & ADA & 142 & 8 & 15.6 & 0.019 & Sandborn et $\mathrm{al}^{25}$ \\
\hline & Placebo & 152 & & 9.3 & & \\
\hline \multirow[t]{3}{*}{ UC } & Golimumab $400 \mathrm{mg} / 200 \mathrm{mg}$ & 257 & 6 & 17.9 & $<0.00 \mathrm{I}$ vs placebo & Sandborn et $\mathrm{al}^{26}$ \\
\hline & Golimumab $200 \mathrm{mg} / 100 \mathrm{mg}$ & 253 & & 17.8 & $<0.001$ vs placebo & \\
\hline & Placebo & 251 & & 6.4 & & \\
\hline
\end{tabular}

Abbreviations: CD, Crohn's disease; UC, ulcerative colitis; ADA, adalimumab; CZP, certolizumab pegol; NS, not significant; IFX, infliximab; AZA, azathioprine; CRP, C-reactive protein; vs, versus.

biologic therapy in $\mathrm{CD}$ is more effective in achieving mucosal healing than episodic treatment. ${ }^{28}$

Of note, Schnitzler et $\mathrm{al}^{29}$ showed that at a median time of 6.7 months (interquartile range 1.4-24.6) after the start of IFX therapy in a CD cohort, there was mucosal healing noted in $68 \%$ of 183 initial responders, with 83 patients $(45.4 \%)$ having complete healing and 41 (22.4\%) having partial healing. Scheduled IFX treatment from the start resulted in mucosal healing more frequently than episodic treatment. The annual risk for loss of response to IFX averages about 13\% per patient-year of treatment, ${ }^{30}$ and for ADA the corresponding estimate is $20.3 \% .{ }^{31}$ When CD patients lose response after two anti-TNF- $\alpha$ agents, it is still possible that a third drug of the same class may be beneficial. ${ }^{32}$

\section{Efficacy of anti-TNF- $\alpha$ medication in UC}

The first anti-TNF- $\alpha$ agent approved for use in UC treatment was IFX. In the Active Ulcerative Colitis Trials (ACT) 1 and 2, patients with moderate-to-severe active UC treated with IFX were more likely to have a clinical response at week 8 than those receiving placebo. ${ }^{23}$ Over $60 \%$ of patients on IFX ( $5 \mathrm{mg} / \mathrm{kg}$ and $10 \mathrm{mg} / \mathrm{kg}$ dosages) had a clinical response by week 8 versus $37 \%$ for placebo. Mucosal healing was significantly increased in the IFX group compared with placebo. In $\mathrm{UC}$, the remission rates were reported by Ford et $\mathrm{al}^{11}$ as $57.1 \%$ for IFX (at weeks 6-12) and 17\% for ADA (at week 6).

It has been shown more recently that newer anti-TNF- $\alpha$ agents $\mathrm{ADA}^{24,25}$ and golimumab ${ }^{26}$ are also effective in induction of remission in patients with extensive UC. In an 8-week placebo-controlled study, 186 patients (resistant to steroids and immunomodulator therapy, anti-TNF-naïve) were given ADA (160 mg at week 0, $80 \mathrm{mg}$ at week 2, and $40 \mathrm{mg}$ at weeks 4 and 6 or $80 \mathrm{mg}$ at week 0 and $40 \mathrm{mg}$ at weeks 2, 4, and 6) or placebo. At week 8 there was a significantly higher remission rate with ADA 160/80/40 than with placebo, $18.5 \%$ versus $9.2 \%$, but no difference with the 
$80 / 40$ regime. ${ }^{24}$ Table 2 summarizes the early remission rates of four placebo-controlled trials of biologic therapy in UC patients. Remission rates in UC at 8 weeks were $36 \%$ with IFX and half that rate with ADA. The remission rate in UC patients treated with golimumab resembled that achievable with ADA. These data are important when early introduction of biologic therapy in UC is considered. It would appear that IFX is the drug of choice for initial biologic therapy, since it has the higher remission rate. As was found with $\mathrm{CD}$, the combination of IFX with an immunomodulator in UC patients gives better results than IFX alone. ${ }^{33} \mathrm{Lv}$ et $\mathrm{al}^{34}$ have meta-analyzed eight trials (2,122 patients) receiving TNF- $\alpha$ blockers (IFX in seven studies, ADA in one study) or placebo for severe UC through 2012. There was clinical benefit for IFX or ADA as compared with placebo in terms of an increased frequency of clinical remission $(P<0.00001)$, steroid-free remission $(P=0.01)$, and endoscopic remission $(P<0.00001)$. In three trials there was a reported decreased rate of colectomy $(P=0.03)$.

Laharie et $\mathrm{al}^{35}$ performed the only study that compared rescue IFX and cyclosporine treatments for severe UC $(n=115)$; both drugs were effective, and no difference was found in mucosal healing $(P=0.85)$, colectomy frequency $(P=0.60)$, or serious adverse events (SAEs) $(P=0.23)$. Given these impressive findings, cyclosporine is no longer considered the rescue therapy of first choice in fulminant UC. Considering UC patients failing rescue therapy and then going to colectomy, there is no consensus in the literature as to whether anti-TNF- $\alpha$ therapies can increase the risk of postoperative complications, so this consideration cannot detract from the possible benefit of giving IFX to these very sick patients. There are no reports of early biologic intervention in UC, but the results of short-term therapy with biologics shown in Table 2 can be taken as an indication of the likely response to early interventional biologic treatment.

Stidham et $\mathrm{al}^{36}$ reported a network meta-analysis of the efficacy of three anti-TNF- $\alpha$ agents for the treatment of UC, based on a selection of six trials for induction response. This meta-analysis demonstrated that, compared with placebo, IFX, ADA, and golimumab were all effective for the induction of remission in $\mathrm{UC}$, and that no single agent was statistically superior to the others for the end points of induction of remission $(P=0.071)$ or response $(P=0.025)$, although there was a trend in favor of IFX.

\section{Non-anti-TNF agents in IBD}

Approximately a third of patients fail treatment with TNF- $\alpha$ antagonists, and up to $40 \%$ of patients who initially benefit subsequently lose response over time. Accordingly, new therapeutic approaches are being developed. The cytokines interleukin (IL)-12 and IL-23 play a key role in T helper cell and innate lymphocyte cell differentiation and expansion. They are composed of a shared p40 chain, which pairs with a p35 or a p19 chain to form IL-12 and IL-23, respectively. Genome-wide association studies have indicated that variants of the gene encoding the IL-23 receptor, as well as the locus harboring the gene encoding the p40 chain, confer a genetic risk for developing $\mathrm{CD}$. Ustekinumab is a fully human IgG1-K mAb to the $\mathrm{p} 40$ subunit shared by IL-12 and IL-23, and has demonstrated clinical benefit (but not clinical remission) over placebo in a large Phase IIb dose-finding trial in moderate-to-severe CD patients who had failed anti-TNF- $\alpha$ therapy. ${ }^{37}$ Forty percent of treated patients (ustekinumab $6 \mathrm{mg} / \mathrm{kg}$ ) reached the 6 -week primary end point with clinical response of a $>100$ point decrease of the baseline CDAI, as compared with $24 \%$ for placebo $(P=0.005)$. Mucosal healing was impossible to assess because of small sample sizes. There were important safety concerns with ustekinumab. The potential place of this agent in the paradigm of treatments of $\mathrm{CD}$ is not known as yet, nor do we comprehend its possible role in anti-TNF- $\alpha$-naïve patients.

Lobatón et $\mathrm{al}^{38}$ have reviewed the drugs targeting the $\mathrm{a} 4 \mathrm{~b} 1, \mathrm{a} 4 \mathrm{~b} 7$, or aEb7 integrins as well as the ICAM-1 and MAdCAM-1 addressins and the chemokine receptor 9. These drugs reduce intestinal inflammation by preventing T-lymphocyte homing in the gut. Vedolizumab, an a4b7 antibody that produces gut-selective blockade of lymphocyte trafficking, has now completed Phase III trials with very positive results Sandborn et $\mathrm{al}^{39}$ conducted a large, Phase III, randomized, double-blind, placebo-controlled trial of vedolizumab (300 mg intravenously at times 0 and 2 weeks) in moderate to severely active CD patients; $15 \%$ of patients entered clinical remission at week 6 versus $7 \%$ on placebo -a significant difference. These low response rates were attributed to confounding factors. ${ }^{42}$ In active UC, vedolizumab was at least twice as effective as placebo in inducing remission at 6 weeks, $47 \%$ versus $26 \%(P<0.001) .{ }^{41}$ Vedolizumab has a slower onset of action than the anti-TNF- $\alpha$ agents and a longer half-life. Further work is needed to determine its exact place in the algorithm of early biologic intervention for IBD treatment. It could serve as a second-line biologic for patients failing anti-TNF- $\alpha$ drugs within a time span of 4-8 weeks. It could be a first-line medication in subsets of patients yet to be defined, and in those persons with contraindications to anti-TNF- $\alpha$ drugs, such as those with multiple sclerosis. Finally, the effect of this therapy in perianal disease and 
extraintestinal manifestations needs to be investigated. The FDA approval of vedolizumab (to be marketed as Entyvio) for use in refractory CD and UC in May 2014 is a positive step forward, and we await the outcomes of this treatment in large cohorts of difficult patients.

Etrolizumab is a humanized $\mathrm{mAb}$ that selectively binds the $\beta 7$ subunit of the heterodimeric integrins $\alpha 4 \beta 7$ and $\alpha E \beta 7$. In a Phase II trial in patients with moderate-to-severe UC refractory to standard therapy (and anti-TNF-naïve), etrolizumab given subcutaneously over 8 weeks produced rather modest rates of remission by 10 weeks compared with placebo, which was quite ineffective. ${ }^{41}$ This agent is one of several that are in Phase II or III clinical trials in UC. For this agent, it is premature to make conclusions or recommendations.

Natalizumab is a recombinant, humanized, IgG4 mAb to $\alpha 4$ integrin. Natalizumab blocks both $\alpha-4$ B1 integrin (VCAM-1) and $\alpha-4$ B7 integrin (MAdCAM-1) interactions; it inhibits leukocyte adhesion and migration into inflamed tissue (bowel and other). It has been shown to be an efficacious agent for induction of remission in patients with $C D$ who failed anti-TNF- $\alpha$ agents. A retrospective case review of $69 \mathrm{CD}$ patients (failures of standard as well as two antiTNF- $\alpha$ therapies) treated with natalizumab at six sites in Massachusetts, USA, showed that $69 \%$ had a partial or complete clinical response. ${ }^{42}$ This rate is similar to that described with IFX. ${ }^{25}$ Natalizumab has been described as more effective in nonpenetrating $\mathrm{CD}$ disease. ${ }^{43}$ The great fear with the use of natalizumab is the occurrence of progressive multifocal leukoencephalopathy. Accordingly, the use of this agent has been severely restricted to those CD patients resistant to all other forms of therapy, and its place in the armamentarium of anti-IBD drugs is still unclear.

In Table 3 we have summarized the current clinical approaches to the use of biologic medications in $\mathrm{CD}$ and UC patients.

\section{Economic considerations: the cost of biologic treatments}

In the prebiologic era (for practical purposes, just over 15 years ago), the cost of treating $\mathrm{CD}$ and $\mathrm{UC}$ was driven strongly by charges for hospitalization and surgery. ${ }^{44-51}$ With the advent of biologic therapy, this situation has changed completely, and it is now the cost of biologic agents that accounts for the main expenditure in treating these patients. ${ }^{52-56}$ The use of biologic agents actually increases the cost of managing patients, at least in the short term, since their acquisition costs are high.

In the absence of long-term follow-up of patient cohorts to determine health care costs and savings after biologic therapy, cost studies and economic evaluations have been carried out using decision analytic models of hypothetical patients. These models are based on assumptions of changes in health status and make use of quality of life assessments (ie, utility weights) as reported in the literature. Since clinical reports vary greatly in their methodology, and CD and UC

Table 3 Paradigm: use of biologics in inflammatory bowel disease

\begin{tabular}{|c|c|c|c|c|}
\hline $\begin{array}{l}\text { Clinical } \\
\text { scenario }\end{array}$ & Step-up first-line therapy & $\begin{array}{l}\text { Step-up second-line } \\
\text { therapy }\end{array}$ & $\begin{array}{l}\text { Early biologic } \\
\text { therapy }\end{array}$ & Stopping rule (possible) \\
\hline $\begin{array}{l}\text { Mild first attack, } \\
C D \text { or UC }\end{array}$ & Standard* & Immunosuppression** & $\begin{array}{l}\text { Usually not } \\
\text { indicated }\end{array}$ & $\begin{array}{l}\text { Single attack with remission } \\
\text { and mucosal healing in patient } \\
\text { unwilling to continue medication }\end{array}$ \\
\hline $\begin{array}{l}\text { Severe first or } \\
\text { subsequent attack, } \\
\text { CD or UC }\end{array}$ & Accelerated standard & $\begin{array}{l}\text { Rapid introduction } \\
\text { of biologic }\end{array}$ & $\begin{array}{l}\text { Indicated in high- } \\
\text { risk patients*** }\end{array}$ & None \\
\hline $\begin{array}{l}\text { Fistulous and } \\
\text { perianal } C D\end{array}$ & $\begin{array}{l}\text { Standard, biologic in selected } \\
\text { cases }\end{array}$ & Biologic & Indicated & None \\
\hline $\begin{array}{l}C D \text {, short } \\
\text { strictures }\end{array}$ & Endoscopic/surgical dilatation & $\begin{array}{l}\text { Requires maintenance } \\
\text { therapy (likely } \\
\text { azathioprine) }\end{array}$ & $\begin{array}{l}\text { Indicated if there is } \\
\text { evidence of acute } \\
\text { inflammation }\end{array}$ & None \\
\hline UC, strictures & Surgery & None & Not indicated & $\begin{array}{l}\text { After panproctocolectomy } \\
\text { in absence of pouchitis }\end{array}$ \\
\hline $\begin{array}{l}\text { Postoperative } \\
C D\end{array}$ & $\begin{array}{l}\text { Continue the immunomodulator } \\
\text { or biologic used preoperatively }\end{array}$ & $\begin{array}{l}\text { Biologic (of same } \\
\text { or another class) }\end{array}$ & & Not advised \\
\hline
\end{tabular}

Notes: *5-aminosalicylic acid (in UC), corticosteroids (consider budesonide in CD), consider MMX preparations; **azathioprine or 6-mercaptopurine preferred; ***refers to factors indicating a poor prognosis, such as onset in children or young adults, extensive disease and/or extraintestinal manifestations at presentation, terminal ileum location, stricturing and/or penetrating behavior, genetic/serological markers, and family history of inflammatory bowel disease. In every case, it is necessary to fit the treatment paradigm to the specific needs of the particular patient, including patient preferences and the availability and cost of medications. Abbreviations: CD, Crohn's disease; MMX, Multi-Matrix System; UC, ulcerative colitis. 
are diseases with a broad and varying clinical spectrum, there will be large disparities between various models. Herein follows a review of a few pertinent studies, with the objective of determining the economic impact of the use of biologics. As health care budgets become more restricted in all countries with the passage of time, CEAs are increasingly being used to inform coverage and reimbursement decisions in many countries. These analyses have been used recently to assess whether new biologic agents are cost-effective and provide "good value for money". Using the Tufts Medical Center Cost-Effectiveness Analysis Registry, ${ }^{57}$ we identified 38 publications reporting on interventions for $\mathrm{CD}$ and $\mathrm{UC}$, of which 13 examined biologic agents (ten for $\mathrm{CD}$ and three for UC). The results from these analyses are presented in Tables 4 and 5, pertaining to $\mathrm{CD}^{58-67}$ and $\mathrm{UC},{ }^{68-70}$ respectively.

The cost-effectiveness in CD of IFX, ADA, certolizumab, and natalizumab was assessed in ten studies conducted in the US $(\mathrm{N}=4)$, the UK $(\mathrm{N}=4)$, Canada $(\mathrm{N}=1)$, and Italy $(\mathrm{N}=1)$. ICERs varied widely. Some of the treatment regimens were both more effective and cost-saving, while others were associated with very high ICERs. The evaluations varied widely in regard to patient characteristics, regimens compared, and product dosing. For example, Tang et $\mathrm{al}^{60}$ suggested that ADA was cost-saving when compared with natalizumab but was not cost-effective when compared with certolizumab. ADA and IFX seem to be cost-effective treatment options in various patients and countries. However, induction therapy followed by maintenance therapy is not cost-effective regardless of the drug used. ${ }^{61}$ The cost-effectiveness of biologic agents for treating patients with UC has been assessed in three studies from the UK and Canada. When compared with usual care, treating moderate to severely acute UC patients with IFX seems to be cost-effective. However, an assessment of a sequential therapy of IFX and ADA in refractory UC patients suggests that this treatment modality does not provide good value for money.

Our review of economic evaluations has several limitations. Firstly, we did not evaluate the merit and accuracy of the data used for CEAs, nor did we assess the quality of modeling assumptions and the robustness of study findings. Results of CEAs may differ among countries even if the same target population, treatment, comparator, and treatment efficacy are used. This is mainly due to differences in the relative cost of the drugs, and differences in utilization of health care services and their price and charges. Secondly, results may also vary when different follow-up periods are applied, mainly because of the cost of the drug when a long maintenance treatment is applied. Studies using decision analytic models rather than patient-level data may use different assumptions on the target population, which may influence the results. For example, Saito et $\mathrm{al}^{58}$ used a hypothetical cohort of 25-year-old men weighting $60 \mathrm{~kg}$ followed for 1 year, while Blackhouse et $\mathrm{al}^{61}$ assumed a cohort of those aged 37 years weighing $73 \mathrm{~kg}$ and being followed for a period of 5 years. Moreover, although all CEAs presented in our review were conducted from a health care payer's perspective, analyses conducted from a broader societal perspective, considering also indirect costs to the patient, the caregivers, and society, may reach different conclusions. Thirdly, to allow comparison among studies, our review is limited to CEAs reporting a cost per QALY ratio. It is possible that economic evaluations of biologic agents for CD and UC have used other metrics. Finally, our economic review was limited to English language peer-reviewed literature indexed in MEDLINE and published from 2007 to 2014. We did not include health technology assessment reports generated by health technology assessment agencies such as the National Institute for Health and Care Excellence (in England). Of interest, the recent economic review by Tang et $\mathrm{al}^{71}$ yielded similar conclusions regarding the reported studies of biologic agents used to treat $\mathrm{CD}$, but they did not include analyses of biologic interventions for treating $\mathrm{UC}$.

Given the great expense involved in treating IBD patients with biologic therapies, and noting the pivotal role of these agents in altering the natural history of disease and offering the chance to avoid serious complications and surgery, attention must be paid to the provision of these compounds in countries with limited resources. Indeed, biologic therapy is now available for many diseases, and this development will likely continue. Rogler et $\mathrm{al}^{72}$ have reviewed this topic regarding IBD patients at length. Developing countries account for the majority of the world population, and IBD incidence has risen alarmingly in those populations as they become more Westernized. The health care systems in these countries will have difficulty affording such high-priced treatments. A dialogue was suggested as to how the IBD experience of the developed countries could be transferred to those countries with limited resources in order to best identify those patients with a prospect of a severe prognosis. Furthermore, joint involvement of the World Health Organization, the World Gastroenterology Organization, and the pharmaceutical industry is recommended. The World Gastroenterology Organization uses CEAs in making recommendations for the treatment of IBD in developing countries, and the World Health Organization has established threshold limits for intervention cost-effectiveness based on the GDP per region. 
Table 4 Cost-effectiveness analyses of biologic agents for CD

\begin{tabular}{|c|c|c|c|c|c|}
\hline Intervention, comparator, and target population & Country & Time horizon & Study perspective & ICER (\$/QALY) & Reference \\
\hline $\begin{array}{l}\text { Combination therapy with IFX }+ \text { AZA at } 2.5 \mathrm{mg} / \mathrm{kg} \\
\text { daily versus IFX monotherapy (IV infusion } 5 \mathrm{mg} / \mathrm{kg} \\
\text { at weeks } 0,2,6 \text {, and every } 8 \text { weeks thereafter) } \\
\text { in men aged } 25 \text { years with biologically naive CD } \\
\text { refractory to conventional non-anti-TNF- } \alpha \text { therapy }\end{array}$ & UK & I year & Health care payer & 50,000 & Saito et a ${ }^{58}$ \\
\hline $\begin{array}{l}\text { Top-down strategy: induction treatment of combined } \\
\text { immunosuppressive therapy with IFX ( } 2.5 \mathrm{mg} / \mathrm{kg} / \text { day }) \\
\text { and if symptom exacerbation occurred, additional } \\
\text { IFX infusions and methylprednisone ( } 32 \mathrm{mg} / \text { day } \\
\text { for } 3 \text { weeks followed by } 4 \mathrm{mg} / \text { week dose tapering) } \\
\text { prescribed versus step-up strategy: induction treatment } \\
\text { of methylprednisone and if symptom exacerbation } \\
\text { or relapse occurred, AZA and IFX were added to } \\
\text { treatment in newly diagnosed patients with luminal CD }\end{array}$ & Italy & 5 years & Health care payer & Cost-saving & Marchetti et al ${ }^{59}$ \\
\hline $\begin{array}{l}\text { ADA versus CZP in US adult patients aged } 35 \text { years } \\
\text { with moderate-to-severe } C D \text { who failed to respond } \\
\text { to standard therapy }\end{array}$ & US & 54 weeks & Health care payer & Cost-saving & Tang et $\mathrm{a}^{60}$ \\
\hline $\begin{array}{l}\text { Natalizumab versus CZP in US adult patients aged } \\
35 \text { years with moderate-to-severe CD who failed } \\
\text { to respond to standard therapy }\end{array}$ & US & 54 weeks & Health care payer & 300,000 & Tang et $a^{60}$ \\
\hline $\begin{array}{l}\text { ADA versus natalizumab in US adult patients aged } \\
35 \text { years with moderate-to-severe CD who failed } \\
\text { to respond to standard therapy }\end{array}$ & US & 54 weeks & Health care payer & Cost-saving & Tang et $\mathrm{a}^{60}$ \\
\hline $\begin{array}{l}\text { IFX versus natalizumab in US adult patients aged } \\
35 \text { years with moderate-to-severe CD who failed } \\
\text { to respond to standard therapy }\end{array}$ & US & 54 weeks & Health care payer & Cost-saving & Tang et a ${ }^{160}$ \\
\hline $\begin{array}{l}\text { IFX versus CZP in US adult patients aged } 35 \text { years } \\
\text { with moderate-to-severe } C D \text { who failed to respond } \\
\text { to standard therapy }\end{array}$ & US & 54 weeks & Health care payer & Cost-saving & Tang et $\mathrm{a}^{60}$ \\
\hline $\begin{array}{l}\text { Induction therapy of IFX ( } 5 \mathrm{mg} / \mathrm{kg}) \text { infusions followed } \\
\text { by maintenance therapy of IFX ( } 5 \mathrm{mg} / \mathrm{kg} \text { ) infusions } \\
\text { every } 8 \text { weeks versus induction therapy of ADA } \\
(160 \mathrm{mg} \text { ) subcutaneous injections followed by } \\
\text { maintenance therapy of ADA ( } 40 \mathrm{mg}) \\
\text { subcutaneous injections every } 2 \text { weeks in Canadian } \\
\text { patients aged } 37 \text { years and weighing } 73 \mathrm{~kg}\end{array}$ & Canada & 5 years & Health care payer & 470,000 & $\begin{array}{l}\text { Blackhouse } \\
\text { et } \mathrm{a}^{61}\end{array}$ \\
\hline $\begin{array}{l}\text { Induction therapy of IFX ( } 5 \mathrm{mg} / \mathrm{kg}) \text { infusions } \\
\text { followed by maintenance therapy of IFX ( } 5 \mathrm{mg} / \mathrm{kg}) \\
\text { infusions every } 8 \text { weeks versus usual care: variety } \\
\text { of conventional non-anti-TNF- } \alpha \text { treatments including } \\
\text { corticosteroids and other immunosuppressants in } \\
\text { Canadian patients aged } 37 \text { years with refractory CD }\end{array}$ & Canada & 5 years & Health care payer & 230,000 & $\begin{array}{l}\text { Blackhouse } \\
\text { et } \mathrm{a}^{61}\end{array}$ \\
\hline $\begin{array}{l}\text { Induction therapy of ADA ( } 160 \mathrm{mg} \text { ) subcutaneous } \\
\text { injections followed by maintenance therapy of ADA } \\
\text { ( } 40 \mathrm{mg} \text { ) subcutaneous injections every } 2 \text { weeks versus } \\
\text { usual care: variety of conventional non-anti-TNF- } \alpha \\
\text { treatments including corticosteroids and other } \\
\text { immunosuppressants in Canadian patients aged } \\
37 \text { years and weighing } 73 \mathrm{~kg}\end{array}$ & Canada & 5 years & Health care payer & 200,000 & $\begin{array}{l}\text { Blackhouse } \\
\text { et al }\end{array}$ \\
\hline $\begin{array}{l}\text { CZP ( } 400 \mathrm{mg} \text { ) subcutaneously and continued on } \\
\text { monthly maintenance therapy versus natalizumab } \\
\text { ( } 300 \mathrm{mg} \text { ) intravenously every month in US patients } \\
\text { aged } 35 \text { years with moderate-to-severe CD } \\
\text { unresponsive to prior TNF- } \alpha \text { antagonists }\end{array}$ & US & I year & Health care payer & 590,000 & $\begin{array}{l}\text { Ananthakrishnan } \\
\text { et a }{ }^{62}\end{array}$ \\
\hline $\begin{array}{l}\text { ADA versus IFX in US patients with moderately } \\
\text { to severely active } C D\end{array}$ & US & 56 weeks & Health care payer & Cost-saving & Yu et $\mathrm{al}^{63}$ \\
\hline
\end{tabular}


Table 4 (Continued)

\begin{tabular}{|c|c|c|c|c|c|}
\hline Intervention, comparator, and target population & Country & Time horizon & Study perspective & ICER (\$/QALY) & Reference \\
\hline $\begin{array}{l}\text { ADA } 2 \text { years of treatment versus standard care in } \\
\text { moderate to severely active } C D \text { patients in the UK }\end{array}$ & UK & 60 years & Health care payer & 23,000 & Bodger et $\mathrm{al}^{64}$ \\
\hline $\begin{array}{l}\text { ADA I year of treatment versus standard care in } \\
\text { moderate to severely active } C D \text { patients in the UK }\end{array}$ & UK & 60 years & Health care payer & 16,000 & Bodger et al ${ }^{64}$ \\
\hline $\begin{array}{l}\text { IFX } 2 \text { years of treatment versus standard care in } \\
\text { moderate to severely active CD patients in the UK }\end{array}$ & UK & 60 years & Health care payer & 48,000 & Bodger et al ${ }^{64}$ \\
\hline $\begin{array}{l}\text { IFX I year of treatment versus standard care in } \\
\text { moderate to severely active } C D \text { patients in the UK }\end{array}$ & UK & 60 years & Health care payer & 51,000 & Bodger et $\mathrm{al}^{64}$ \\
\hline ADA (every other week) maintenance treatment & UK & I year & Health care payer & 14,000 & Loftus et $\mathrm{a}^{65}$ \\
\hline
\end{tabular}
versus nonbiologic treatment, placebo (also doses of conventional, nonbiologic medications) in $C D$ patients (in two randomized, double-blind placebo-controlled trails, CHARM and CLASSIC, lifetime model duration) (severe disease groups) ADA (every other week) maintenance treatment versus nonbiologic treatment, placebo (also doses of conventional, nonbiologic medications) in CD patients (in two randomized, double-blind placebocontrolled trails, CHARM and CLASSIC, lifetime model duration) (moderately severe disease groups) ADA (every other week) maintenance treatment versus nonbiologic treatment, placebo (also doses of conventional, nonbiologic medications) in CD patients (in two randomized, double-blind placebocontrolled trails, CHARM and CLASSIC, 56-week model duration) (moderately severe disease groups) ADA (every other week) maintenance treatment versus nonbiologic treatment, placebo (also doses of conventional, nonbiologic medications) in $C D$ patients (in two randomized, double-blind placebocontrolled trails, CHARM and CLASSIC, 56-week base case model) (severe disease group) ADA (every other week) maintenance treatment versus nonbiologic treatment, placebo (also doses of conventional, nonbiologic medications) in CD patients (in two randomized, double-blind placebocontrolled trails, CHARM and CLASSIC, 56-week base case model) (severe disease group) Maintenance therapy with IFX $(5 \mathrm{mg} / \mathrm{kg})$ versus standard care without IFX in adult patients with fistulizing $C D$ in the UK

Maintenance therapy with IFX $(5 \mathrm{mg} / \mathrm{kg})$ versus standard care without IFX in adult patients with active luminal $C D$ in the UK

Dose escalation of IFX to $10 \mathrm{mg} / \mathrm{kg}$ versus IFX discontinued and ADA initiated with a $160 \mathrm{mg}$ injection followed by a $80 \mathrm{mg}$ dose 2 weeks later, maintenance of $40 \mathrm{mg}$ every other week in CD patients who have lost response to standard dose $(5 \mathrm{mg} / \mathrm{kg}) \mathrm{IFX}$ therapy

Notes: Study perspective: The study perspective is the viewpoint from which costs and benefits are calculated. All studies included in our review were conducted from a health care payer perspective and include only direct costs incurred by insurance companies (private or national health care service). Time horizon: The time horizon is the length of time in which resource use (eg, drug use, hospital admissions) are measured. ICER is calculated by dividing the incremental cost by the incremental QALYs gained of an intervention over the examined comparator. An ICER is not calculated when the intervention costs less (cost-saving) and is at least as effective as the comparator. In many of these cases, the intervention is considered "dominant" over the comparator, suggesting that it is both cost-saving and more effective.

Abbreviations: CD, Crohn's disease; ICER, incremental cost-effectiveness ratio; QALY, quality-adjusted life-year; IFX, infliximab; AZA, azathioprine; IV, intravenous; TNF, tumor necrosis factor; ADA, adalimumab; CZP, certolizumab pegol; CHARM, Crohn's Trial of the Fully Human Antibody Adalimumab for Remission Maintenance; CLASSIC, CLinical assessment of Adalimumab Safety and efficacy Studied as Induction therapy in Crohn's disease. 
Table 5 Cost-effectiveness analyses of biologic agents for UC

\begin{tabular}{|c|c|c|c|c|c|}
\hline Intervention, comparator, and target population & Country & Time horizon & Study perspective & ICER (\$/QALY) & Reference \\
\hline $\begin{array}{l}\text { IFX, includes first infusion of } 5 \mathrm{mg} / \mathrm{kg} \text { on the } 4 \text { th day, } \\
\text { with concomitant standard care comprising IV therapy } \\
\text { for an additional } 7 \text { days during the hospital stay versus } \\
\text { cyclosporine, includes infusion of } 4 \mathrm{mg} / \mathrm{kg} \text { on the } 4 \text { th } \\
\text { to I I th days, with concomitant standard care } \\
\text { comprising IV therapy for an additional } 7 \text { days during } \\
\text { the hospital stay in acute severe UC patients not } \\
\text { responding to } 72 \text { hours of IV steroid therapy }\end{array}$ & UK & I year & Health care payer & $4 I, 000$ & Punekar et al ${ }^{68}$ \\
\hline $\begin{array}{l}5 \mathrm{mg} / \mathrm{kg} \text { and } 10 \mathrm{mg} / \mathrm{kg} \mathrm{IFX}+\text { ADA versus usual care } \\
\text { in Canadian patients diagnosed with refractory UC }\end{array}$ & Canada & 5 years & Health care payer & 590,000 & Xie et $\mathrm{al}^{69}$ \\
\hline $\begin{array}{l}5 \mathrm{mg} / \mathrm{kg} \text { IFX + ADA versus usual care in Canadian } \\
\text { patients diagnosed with refractory UC }\end{array}$ & Canada & 5 years & Health care payer & 370,000 & Xie et $\mathrm{al}^{69}$ \\
\hline $\begin{array}{l}\text { IFX treatment } 5 \mathrm{mg} / \mathrm{kg} \text {, remission strategy versus standard } \\
\text { care in patients with moderate-to-severe } U C \text { in the UK }\end{array}$ & UK & 10 years & Health care payer & 44,000 & Tsai et $\mathrm{al}^{70}$ \\
\hline $\begin{array}{l}\text { IFX treatment } 5 \mathrm{mg} / \mathrm{kg} \text {, responder strategy versus standard } \\
\text { care in patients with moderate-to-severe UC in the UK }\end{array}$ & UK & 10 years & Health care payer & 62,000 & Tsai et $\mathrm{al}^{70}$ \\
\hline
\end{tabular}

Notes: Study perspective: The study perspective is the viewpoint from which costs and benefits are calculated. All studies included in our review were conducted from a health care payer perspective and include only direct costs incurred by insurance companies (private or national health care service). Time horizon: The time horizon is the length of time in which resource use (eg, drug use, hospital admissions) are measured. ICER is calculated by dividing the incremental cost by the incremental QALYs gained of an intervention over the examined comparator. An ICER is not calculated when the intervention costs less (cost-saving) and is at least as effective as the comparator. In many of these cases, the intervention is considered "dominant" over the comparator, suggesting that it is both cost-saving and more effective.

Abbreviations: UC, ulcerative colitis; ICER, incremental cost-effectiveness ratio; QALY, quality-adjusted life-year; IFX, infliximab; IV, intravenous; ADA, adalimumab.

Of importance, endemic diseases such as tuberculosis and intestinal parasites need to be excluded, and a trial of therapy may be indicated where differentiation from CD and UC is difficult or limited by lack of resources. Biologic therapy can also be harmful in persons with chronic hepatitis, a condition that is more common in developing nations, and in those with human immunodeficiency virus. There are particular ethical considerations regarding poorer countries that have no easy solutions.

\section{Adverse effects of biologic therapies}

As with all medications, it is important to consider the side effects reported with biologic therapies. The anti-TNF- $\alpha$ medications are usually well tolerated, but adverse events resulted in up to $15 \%$ of patients withdrawing from clinical trials. Injection site and infusion reactions were highest with IFX and lowest with CZP. Infusion reactions can be prevented in most cases by coadministration of hydrocortisone. Delayed hypersensitivity reactions are uncommon and can appear within a few days after treatment. Infections may be more common after anti-TNF- $\alpha$ administration, including activation of latent tuberculosis and hepatitis B. Proper screening procedures and immunizations are thus advised before biologics are prescribed. Malignancy after antiTNF- $\alpha$ therapy is an important concern, particularly the rare hepatosplenic T-cell lymphoma in young men and nonmelanotic skin cancer. A recent Cochrane review looked at SAEs, activation of tuberculosis, lymphoma, and congestive cardiac failure after biologic therapy in a variety of diseases in the short term. ${ }^{73}$ Of the anti-TNF- $\alpha$ agents, IFX had significantly more adverse events than placebo (OR 1.55, 95\% confidence interval 1.01-2.35) and the largest number of patient withdrawals from drug trials (OR 2.34, 1.40-4.14) compared with the other biologics. CZP had the highest risk of serious infections (OR 4.75, 1.52-18.5) and SAEs (OR 1.57, 1.06-2.32). CZP had significantly more SAEs than ADA, and ADA more than golimumab. Lymphoma and cardiac failure were not more common after biologic therapy compared with control subjects. Natalizumab, as noted, has been associated with the onset of progressive multifocal leukoencephalopathy caused by the JC virus. ${ }^{74}$ Other newer biologics had a reported $10 \%$ rate of adverse events. The issue of whether biologic agents increase perioperative morbidity remains an open question.

\section{The patient's perspective}

Patients seek clinical improvement and an increased quality of life, and are confused by new and unknown treatments. It is increasingly recognized that the patients must be given time to express their opinions about choice of therapy and related cost issues. The European Federation of Crohn's and Ulcerative Colitis Associations has studied the subject of patient-physician communication and found that nearly half of IBD patients do not initiate discussion of quality of life issues with their doctors. ${ }^{75}$ We emphasize here the great importance of such discourse, particularly when biologic 
therapy is considered, given both its cost and potential for adverse events, and endorse the federation's recommendation for a "prescription for information" personalized to the exact sociodemographic and clinical situation of the patient.

\section{Conclusion}

In clinical terms, the choice of a biologic agent in $\mathrm{CD}$ or UC seems now to depend on patient preference of route of administration and on availability (this latter depends principally on cost considerations). There is probably no difference of clinical efficacy between IFX and ADA, although this statement is based on indirect evidence and on a network meta-analysis from one research group. The place of other anti-TNF- $\alpha$ agents is less certain. The available non-anti-TNF agents will likely be used as second-line therapies, although there is no evidence for this statement. Clearly, better identification of subphenotypes of $\mathrm{CD}$ and $\mathrm{UC}$ is required to make these decisions. Regarding IBD-U, this is basically an unresearched entity, and choice of medication will continue to be empirical in the near future.

The introduction of biologic drugs has shifted the cost of treating IBD from hospitalizations and surgical procedures toward anti-TNF- $\alpha$ therapy. A recent study suggests that anti-TNF- $\alpha$ use was the main cost driver, accounting for $64 \%$ and $31 \%$ of the total cost in CD and UC, respectively. ${ }^{58}$ The current high cost of these drugs remains a problem; current evidence suggests that biologic agents may be cost-effective for both CD and UC only under certain specific clinical scenarios. However, these interventions are not cost-saving, suggesting that savings in follow-up costs (for surgery, hospitalization) are not sufficient to offset the cost of the drugs. The number of CEAs published in recent years is rather limited, and it is very difficult to draw conclusions on their economic merit for all indications and target patients, particularly when dealing with diseases with protean manifestations, such as as UC and CD. Important factors such as length and frequency of treatment (ie, induction or maintenance treatment) with each drug, as well as switching among biologic drugs when the first employed agent was ineffective, should be further examined in economic evaluations. The progress of golimumab will be followed keenly both clinically and from the cost aspect. With the new availability of different classes of biologic agents such as vedolizumab, it will be interesting to follow the upcoming clinical and economic evaluations in large patient populations. The introduction of biosimilars in the coming years may improve the cost-effectiveness of biologic agents, due to expected price reductions. This is contingent upon the assumption that biosimilar drugs are as effective clinically as the original patented agents. Finally, the newer biologics undergoing clinical trials or still in the development stage will need to be assessed in the context of health economics.

\section{Disclosure}

The authors report no conflicts of interest in this work.

\section{References}

1. Silverberg MS, Satsangi J, Ahmad T, et al. Toward an integrated clinical, molecular and serological classification of inflammatory bowel disease: report of a working party of the 2005 Montreal World Congress of Gastroenterology. Can J Gastroenterol. 2005;19(Suppl A):5-36.

2. Burisch J, Pedersen N, Čuković-Čavka S, et al. East-West gradient in the incidence of inflammatory bowel disease in Europe: the ECCO-EpiCom inception cohort. Gut. 2014;63(4):588-597.

3. Borg S, Persson U, Jess T, et al. A maximum likelihood estimator of a Markov model for disease activity in Crohn's disease and ulcerative colitis for annually aggregated partial observations. Med Decis Making. 2010;30(1):132-142.

4. Munkholm P, Langholz E, Davidsen M, Binder V. Disease activity courses in a regional cohort of Crohn's disease patients. Scand $J$ Gastroenterol. 1995;30(7):699-706.

5. Blomqvist P, Ekbom A. Inflammatory bowel diseases: health care and costs in Sweden in 1994. Scand J Gastroenterol. 1997;32(11): 1134-1139.

6. Mowat C, Cole A, Windsor A, et al. Guidelines for the management of inflammatory bowel disease in adults. Gut. 2011;60(5):571-607.

7. Blonski W, Buchner AM, Lichtenstein GR. Inflammatory bowel disease therapy: current state-of-the-art. Curr Opin Gastroenterol. 2011;27(4):346-357.

8. Chevaux J-B, Vavricka SR, Rogler G, Lakatos PL, Schoepfer A, PeyrinBiroulet L. Mucosal healing with anti-TNF antibodies. Digestion. 2012;86(Suppl 1):16-22.

9. Odes S. How expensive is inflammatory bowel disease? A critical analysis. World J Gastroenterol. 2005;14(43):6641-6647.

10. Bosani A, Ardizonne S, Porro GB. Biologic targeting in the treatment of inflammatory bowel diseases. Biologics. 2009;3:77-97.

11. Ford AC, Sandborn WJ, Khan KJ, et al. Efficacy of biological therapies in inflammatory bowel disease: systematic review and meta-analysis. Am J Gastroenterol. 2011;106(4):644-659.

12. Kawalec P, Mikrut A, Wiśniewska N, Pilc A. Tumor necrosis factor- $\alpha$ antibodies (infliximab, adalimumab and certolizumab) in Crohn's disease: systematic review and meta-analysis. Arch Med Sci. 2013;9:765-779.

13. Hanauer SB, Sandborn WJ, Rutgeerts P, et al. Human anti-tumor necrosis monoclonal antibody (adalimumab) in Crohn's disease: the CLASSIC-1 trial. Gastroenterology. 2006;130(2):323-333.

14. Sandborn WJ, Rutgeerts P, Enns R, et al. Adalumumab induction therapy for Crohn's disease previously treated with infliximab: a randomized trial. Ann Intern Med. 2007;146(12):829-838.

15. Sandborn WJ, Schreiber S, Feagan BG, et al. Certolizumab pegol for active Crohn's disease: a placebo-controlled, randomized trial. Clin Gastroenterol Hepatol. 2011;9(8):670-678.

16. Winter TA, Wright J, Ghosh S, et al. Intravenous CDP870, a PEGylated Fab' fragment of a humanized antitumour necrosis factor antibody, in patients with moderate-to-severe Crohn's disease; an exploratory study. Aliment Pharmacol Ther. 2004;20(11-12):1337-1346.

17. Schreiber S, Lawrance IC, Thomson O, et al. Randomized clinical trial: certolimumab pegol for fistulas in Crohn's disease: sub-group results from a placebo-controlled study. Aliment Pharmacol Ther. 2011;33(2):185-193. 
18. Colombel JF, Sandborn WJ, Reinisch W, et al. Infliximab, azathioprine, or combination therapy for Crohn's disease. N Engl J Med. 2010; 362(15):1383-1395.

19. Targan SR, Hanauer SB, van Deventer SJ, et al. A short-term study of chimeric monoclonal antibody cA2 to tumor necrosis factor alpha for Crohn's disease. Crohn's disease cA2 Study Group. N Engl J Med. 1997;337(15):1029-1035.

20. D'Haens G, Baert F, van Assche G, et al. Early combined immunosuppression or conventional management in patients with new diagnosed Crohn's disease: an open randomized trial. Lancet. 2008;371(9613): $660-667$.

21. Targan SR, Feagan BG, Fedorak RN, et al. Natalizumab for the treatment of active Crohn's disease: results of the ENCORE trial. Gastroenterology. 2007;136(5):1672-1683.

22. Sandborn WJ, Colombel JF, Enns R, et al. Natalizumab induction and maintemence therapy for Crohn's disease. N Engl J Med. 2005;353(18): 1912-1925

23. Rutgeerts $P$, Sandborn WJ, Feagan BG, et al. Infliximab for induction and maintenance therapy for ulcerative colitis. $N$ Engl J Med. 2005; 353(23):2462-2476.

24. Reinisch W, Sandborn WJ, Hommes DW, et al. Adalimumab for induction of clinical remission in moderately to severely active ulcerative colitis: results of a randomised controlled trial. Gut. 2011;60(6): 780-787.

25. Sandborn WJ, van Assche G, Reinisch W, et al. Adalimumab induces and maintains clinical remission in patients with moderate-to-severe ulcerative colitis. Gastroenterology. 2012;142(5):257-265.

26. Sandborn WJ, Feagan BG, Marano C, et al. Subcutaneous golimumab induces clinical response and remission in patients with moderate-tosevere ulcerative colitis. Gastroenterology. 2014;146(1):85-95.

27. Stidham RW, Lee TCH, Higgins PDR, et al. Systematic review with network meta-analysis: the efficacy of anti-TNF agents for the treatment of Crohn's disease. Aliment Pharmacol Ther. 2014;39(12):1399-1362.

28. Rutgeerts P, Diamond RH, Bala M, et al. Scheduled maintenance treatment with infliximab is superior to episodic treatment for the healing of mucosal ulceration associated with Crohn's disease. Gastrointest Endosc. 2006;63(3):433-442.

29. Schnitzler F, Fidder H, Ferrante M, et al. Mucosal healing predicts long-term outcome of maintenance therapy with infliximab in Crohn's disease. Inflamm Bowel Dis. 2009;15(9):1295-1301.

30. Gisbert JP, Panes J. Loss of response and requirement of infliximab dose intensification in Crohn's disease: a review. Am J Gastroenterol. 2009;104(3):760-767.

31. Ricart E, Ordas I, Panes J. Anti-TNF antibody therapy in Crohn's disease: the risk of a switch. Gut. 2012;61(2):169-170.

32. Allez M, Vermeire S, Mozziconacci N, et al. The efficacy and safety of a third anti-TNF monoclonal antibody in Crohn's disease after failure of two other anti-TNF antibodies. Aliment Pharmacol Ther. 2010;31(1):92-101.

33. Panaccione R, Ghosh S, Middleton S, et al. Combination therapy with infliximab and azathioprine is superior to monotherapy with either agent in ulcerative colitis. Gastroenterology. 2014;146(2):392-400.

34. Lv R, Qiao W, Wu Z, et al. Tumor necrosis factor alpha blocking agents as treatment for ulcerative colitis intolerant or refractory to conventional medical therapy: a meta-analysis. PLos One. 2014;9(1):e86692.

35. Laharie D, Bourreille A, Branche J, et al. Ciclosporin versus infliximab in patients with severe ulcerative colitis refractory to intravenous steroids: a parallel, open-label randomized controlled trial. Lancet. 2012;380(9857):1909-1915.

36. Stidham RW, Lee TC, Higgins PD, et al. Systematic review with network meta-analysis: the efficacy of anti-tumour necrosis factor-alpha agents for the treatment of ulcerative colitis. Aliment Pharmacol Ther. 2014;39(7):660-671.

37. Sandborn WJ, Gasink C, Gao LL, et al. Ustekinumab induction and maintenance therapy in refractory Crohn's disease. $N$ Engl J Med. 2012;367(16):1519-1528.
38. Lobatón T, Vermeire S, Van Assche G, Rutgeerts P. Review article: anti-adhesion therapies for inflammatory bowel disease. Aliment Pharmacol Ther. 2014;39(6):579-594.

39. Sandborn WJ, Feagan BG, Rutgeerts P, et al. Vedolizumab as induction and maintenance therapy for Crohn's disease. $N$ Engl J Med. 2013;369(8):711-721.

40. Parikh A, Leach T, Wyant T, et al. Vedolizumab for the treatment of active ulcerative colitis: a randomized controlled phase 2 dose-ranging study. Inflamm Bowel Dis. 2012;18(8):1470-1479.

41. Vermeire S, O’Byrne S, Keir M, et al. Etrolizumab as induction therapy for ulcerative colitis: a randomized, controlled, phase 2 trial. Lancet. 2014;384(9940):309-318

42. Juillerat P, Wasan SK, Fowler SA, et al. Efficacy and safety of natalizumab in Crohn's disease patients treated at 6 Boston academic hospitals. Inflamm Bowel Dis. 2013;19(11):2457-2463.

43. Sakuraba A, Keyashian K, Correia C, et al. Natalizumab in Crohn's disease: results from a US tertiary inflammatory bowel disease center. Inflamm Bowel Dis. 2013;19(3):621-626.

44. Silverstein MD, Loftus EV, Sandborn WJ, et al. Clinical course and costs of care for Crohn's disease: Markov model analysis of a populationbased cohort. Gastroenterology. 1999;117(1):49-57.

45. Hay AR, Hay JW. Inflammatory bowel disease: medical cost algorithms. J Clin Gastroenterol. 1992;14(4):318-327.

46. Feagan BG, Vreeland MG, Larson LR, Bala MV. Annual cost of care for Crohn's disease: a payor perspective. Am L Gastroenterol. 2000;95(8):1955-1960.

47. Cohen RD, Larson LR, Roth JM, Becker RV, Mummert LL. The cost of hospitalization in Crohn's disease. Am J Gastroenterol. 2000;95(2): 524-530.

48. Bernstein CN, Papineau N, Zajaczkowski J, Rawsthorne P, Okrusko G, Blanchard JF. Direct hospital costs for patients with inflammatory bowel disease in a Canadian tertiary care university hospital. Am J Gastroenterol. 2000;95(3):677-683.

49. Bassi A, Dodd S, Williamson P, Bodger K. Cost of illness of inflammatory bowel disease in the UK: a single centre retrospective study. Gut. 2004;53(10):1471-1478.

50. Ebinger M, Leidl R, Thomas S, et al. Cost of outpatient care in patients with inflammatory bowel disease in a German university hospital. J Gastroenterol Hepatol. 2004;19(2):192-199.

51. Odes S, Vardi H, Friger M, et al. Cost-analysis and cost-determinants in a European inflammatory bowel disease inception cohort with 10 years follow-up evaluation. Gastroenterology. 2006;131(3): 719-728.

52. Bernstein CN, Longobardi T, Finlayson G, Blanchard JF. Direct medical costs of managing IBD patients: a population-based study. Inflamm Bowel Dis. 2012;18(8):1498-1508.

53. Van der Walk ME, Mangen MJ, Leenders M, et al. Healthcare costs of inflammatory bowel disease have shifted from hospitalization and surgery towards anti-TNF therapy: results from the COIN study. Gut. 2014;63(1):72-79.

54. Benedini V, Caporaso N, Corazza GR, et al. Burden of Crohn's disease: economics and quality of life aspects in Italy. Clinicoecon Outcomes Res. 2012;4:209-218.

55. Saro C, de la Coba C, Casad MA, Morales JM, Otero B. Resource use in patients with Crohn's disease treated with infliximab. Aliment Pharmacol Ther. 2007;26(10):1313-1323.

56. Loomes DE, Teshima C, Jacobs P, Fedorak RN. Health care resource use and cost in Crohn's disease before and after infliximab. Can J Gastroenterol. 2011;25(9):497-502.

57. Cost-Effectiveness Analysis Registry [homepage on the Internet]. Available from: https://research.tufts-nemc.org/cear. Boston, MA: Tufts Medical Center. Accessed August 29, 2014.

58. Saito S, Shimizu U, Nan Z, et al. Economic impact of combination therapy with infliximab plus azathioprine for drug-refractory Crohn's disease: a cost-effectiveness analysis. J Crohn's Colitis. 2013;7(2): $167-174$. 
59. Marchetti M, Liberato NL, Di Sabatino A, Corazza GR. Costeffectiveness of top-down versus step-up strategies in patients with newly diagnosed active luminal Crohn's disease. Eur J Health Econ. 2013;14(6):853-861.

60. Tang DH, Armstrong EP, Lee JK. Cost-utility analysis of biologic treatments for moderate-to-severe Crohn's disease. Pharmacotherapy. 2012;32(6):515-526.

61. Blackhouse G, Assasi N, Xie F, et al. Canadian cost-utility analysis of initiation and maintenance treatment with anti-TNF- $\alpha$ drugs for refractory Crohn's disease. J Crohn's Colitis. 2012;6(1):77-85.

62. Ananthankrishnan AN, Hur C, Korzenik JR. Certolizumab pegol compared to natalizumab in patients with moderate to severe Crohn's disease: results of a decision analysis. Dig Dis Sci. 2012;57(2): 472-480.

63. Yu AP, Johnson S, Wang ST, et al. Cost utility of adalimumab versus infliximab maintenance therapies in the United States for moderately to severely active Crohn's disease. Pharmacoeconomics. 2009;27(7):609-621.

64. Bodger K, Kikuchi T, Hughes D. Cost-effectiveness of biological therapy for Crohn's disease: Markov cohort analyses incorporating United Kingdom patient-level cost data. Aliment Pharmacol Ther. 2009;30(3):265-274.

65. Loftus EV Jr, Johnson SJ, Yu AP, Wu EQ, Chao J, Mulani PM. Cost-effectiveness of adalimumab for the maintenance of remission in patients with Crohn's disease. Eur J Gastroenterol Hepatol. 2009;21(11):1302-1309.

66. Lindsay J, PunekarY, Morris J, Chung-Faye G. Health-economic analysis: Cost-effectiveness of scheduled maintenance treatment with infliximab for Crohn's disease - modelling outcomes in active luminal and fistulising disease in adults. Aliment Pharmacol Ther. 2008;28(1):76-87.
67. Kaplan GG, Hur C, Korzenik J, Sands BE. Infliximab dose-escalation vs initiation of adalimumab for loss of response in Crohn's disease: a cost-effectiveness analysis. Aliment Pharmacol Ther. 2007;26(11-12): 1509-1520.

68. Punekar YS, Hawkins N. Cost-effectiveness of infliximab for the treatment of acute exacerbations of ulcerative colitis. Eur J Health Econ. 2010;11(1):67-76

69. Xie F, Blackhouse G, Assasi N, Gaebel K, Robertson D, Goeree R. Costutility analysis of infliximab and adalimumab for refractory ulcerative colitis. Cost Eff Resour Alloc. 2009;11:7:20.

70. Tsai HH, Punekar YS, Morris J, Fortun P. A model of the long-term cost-effectiveness of scheduled maintenance treatment with infliximab for moderate-to-severe ulcerative colitis. Aliment Pharmacol Ther. 2008; 28(10):1230-1239.

71. Tang DH, Harrington AR, Lee JK, Lin M, Armstrong EP. A systematic review of economic studies on biological agents used to treat Crohn's disease. Inflamm Bowel Dis. 2013;19(12):2673-2694.

72. Rogler G, Bernstein CN, Ajit S, et al. Role of biological therapy for inflammatory bowel disease developing countries. Gut. 2012;61(6): 706-712.

73. Singh JA, Wells GA, Christensen R, et al. Adverse effects of biologics: a network meta-analysis and Cochrane overview. Cochrane Database Syst Rev. February 16, 2011;(2):CD008794.

74. Singh JA, Kumar N, Loftus EV Jr, Kane SV. Neurological complications in patients with inflammatory bowel disease: increasing relevance in the era of biologics. Inflamm Bowel Dis. 2013;19(4):864-872.

75. Ghosh S, Mitchell R. Impact of inflammatory bowel disease on quality of life: results of the European Federation of Crohn's and Ulcerative Colitis Associations (EFCCA) patient survey. J Crohn's Colitis. 2007;1:10-20.
ClinicoEconomics and Outcomes Research

\section{Publish your work in this journal}

ClinicoEconomics \& Outcomes Research is an international, peerreviewed open-access journal focusing on Health Technology Assessment, Pharmacoeconomics and Outcomes Research in the areas of diagnosis, medical devices, and clinical, surgical and pharmacologica intervention. The economic impact of health policy and health systems

\section{Dovepress}

organization also constitute important areas of coverage. The manuscript management system is completely online and includes a very quick and fair peer-review system, which is all easy to use. Visit http://www.dovepress.com/testimonials.php to read real quotes from published authors. 